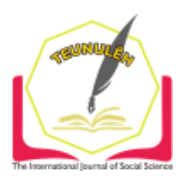

Jurnal Ilmiah Teunuleh

The International Journal of Social Sciences

Vol. 1, Issue. 2, Dec 2020

E-ISSN: 2746-4393

\title{
DEVELOPMENT OF CITIZENSHIP LEARNING BASED ON MORAL INTELLIGENCE AS A SYSTEM PROGRAM FOR CULTURING MAIN CHARACTER VALUES
}

\author{
Deny Setiawan ${ }^{1}$ \\ Arief Wahyudi² \\ ${ }^{1,2}$ Faculty of Social Sciences, Universitas Negeri Medan, Indonesia \\ ${ }^{1}$ denysetiawan1978@gmail.com; ${ }^{2}$ ariefwahyudi@unimed.ac.id
}

\begin{abstract}
This research was motivated by the factual condition of the occurrence of a moral crisis among Indonesia's young generation, including the weak culture of the main character values. This development research was aimed to develop moral intelligence-based Citizenship Education learning as a systemic program for the culture of the main character values. The scope of this research was limited to the study of civics learning based on moral intelligence as a systemic program of cultivating character values among students. The research method was used by the Research \& Development. The research subjects involved: (1) a lecturer who taught introduction courses of civics; (2) students is limited group trials as subject; and (3) three experts for the validation of teaching materials who had criteria for Citizenship Education experts including: politics, law, and moral philosophy. The instrument was used an expert validation questionnaire which was analyzed using the Percentage Mean Score (PRS). The results of the research showed that civics learning textbook based on intelligent moral that developed was very valid and suitable for being used and giving contribution on the strengthen of character for students in their scope life in global era that full of change and value paradoxes.
\end{abstract}

Keywords: Citizenship, moral intelligence, character

\section{A. Introduction}

The journey of the Indonesian state since its inception, Bung Karno emphasized: "This nation must be built with prioritizing character building, because this character building will make Indonesia a great nation" (Soedarsono, 2009). Character is the prima donna for founding fathers in the hopes and aspirations of the nation in the future in filling independence and honoring the dignity and identity of the nation and state. 
This post-reform phenomenon in a situation that is very concerning in the character envisioned by Pancasila, all components of the nation and institutions in this republic should agree to place nation and character building as the main priority. Without intending to isolate the role of other institutions, education as an institution is still considered appropriate to play a role as a forum for building the character of the nation's children (Setiawan, 2017).

By having rigorous character the graduates are expected will be successful when confronting various challenges and changes because of survival of the fittest. In other words, the students are not equipped with hard skills, but other skills such as problem solving, critical thinking, working together must be trained from now because these are required in today's world (Heriansyah, 2018). He stated that character education is very important for the growth of the human individual as a whole and must be done from an early age. So character education for educational institutions must continue to be held for basic education and character building. Because in academic education it is not only important to pay attention to the needs of students' academic competencies but also to build character so that graduates become academically ready and good graduates (Kamaruddin, 2012). His analysis states that civic education is important in the political behavior of individuals and groups of students. Recognizing the nature of politics requires virtue and character education. This also goes hand in hand with character education for students, which plays an important role in the relationship to make a good life related to citizenship (Peterson, 2019).

Medan State University has dared to appoint its institution as a character building university, by establishing six pillars of character, namely: citizenship, justice (fright), honor (respect), responsibility (responsible), care (caring), and can trusted (trustworthy) in taking part in building the character of the nation (Siburian, 2011), (Sinaga, 2011), (Hajar, 2011).

It is assumed that current education tends to prioritize achievement of academic competence rather than achievement of moral competence. Learning in the world of education, which is still dominated by the transfer of knowledge as a result of the growth of a verbalistic learning culture (Sanusi, 1993), is one of the causes of learning implementation which tends to prioritize academic competence. This phenomenon affects character education, which values are only absorbed but not internalized to be practiced. If it was implemented, this would be due to supervision or legal institutions, but not because of self-awareness (Winarni, 2013). 
Development of Citizenship Learning Based on Moral Intelligence as...

The idea of civics learning based on moral intelligence has also been presented externally at the work meeting of Indonesian Pancasila and Civic Education Professional Association. In the AP3Knl work meeting held in Banda Aceh (10-12 October, 2019), Pancasila and Civic Department of Social and Science Faculty, Universitas Negeri Medan is as an active member of the association proposed the need for a moral intelligencebased character education program in universities. The results of the work meeting were agreed upon, it was necessary to have textbooks on character education proposed by each university. This opportunity was used by Pancasila and Civic Education Department of Social and Science Faculty, Universitas Negeri Medan to collaborate between Universitas Negeri Medan and AP3Knl in the form of research with a focus on Civics textbooks based on moral intelligence. Through this research, it is hoped that this collaboration can be realized, and can produce textbooks as a joint reference for Pancasila and Civic majors throughout Indonesia in developing moral competence among academicians and in cultivating the values of the main character.

\section{Literature Review}

Character is a description of individuals in thinking and behaving in their daily behavior, both in family, community and state life. Responsible and bear everything for the decisions that have been chosen is a good individual in life (Suyatno, 2009).

Character education is essentially a value education that involves aspects of knowledge (cognitive), feelings, and action (Kirschenbaum, 2000). According to the view (Lickona, 1991) value / moral education that produces character, there are three components of good character, namely: moral knowledge, moral feeling and moral actions.

Moral knowledge which includes: moral awareness, knowledge of moral values, future views, moral thought, decision making and self-knowledge, are essential things that need to be taught to students. However, character education as a moral knowledge is not enough. For that we need to continue to the moral feeling which includes: conscience, self-confidence, empathy, love of kindness, self-control and humility. It even continues at the most important stage, namely moral action. It is called important because at this stage the motive for a person's encouragement to do well. It can be seen in the aspects of competence, desires and habits that are displayed. The arrangement of three moral components that are synergistically interconnected is a prerequisite for the actualization of character education in developing students' moral intelligence. Moral 
intelligence is the ability to understand right and wrong with strong ethical beliefs and act on those beliefs with the right attitude and respectful behavior (Borba, 2008).

Character education based on moral intelligence is something urgent, because moral intelligence is built from several main virtues which will help students respond to and face life's challenges which are full of contradictions. Furthermore, (Borba, 2008) outlines seven main virtues that students need to have in developing moral intelligence, namely: empathy, conscience, self-control, respect, kindness, tolerance, and justice.

With a character education design based on moral intelligence that is actualized systematically and continuously, students will have a number of main virtues that are useful for them in facing all kinds of life challenges, including challenges to succeed academically. Thus, character education based on moral intelligence is an effort to develop the abilities of students who are oriented towards having intelligence plus character competencies.

In order for character education based on moral intelligence to be carried out effectively, it is necessary to design moral conditioning as an initial stage of implementation. According to Lickona, there are eleven principles so that character education can be carried out effectively: (1) developing universal values as a foundation; (2) defining character comprehensively which includes aspects of thoughts, feelings and behavior; (3) using a comprehensive and proactive approach; (4) creating a caring school community; (5) provide opportunities for students to take moral actions; (6) create a meaningful academic curriculum; (7) encourage the motivation of students; (8) involving all components of the school as a moral learning community; (9) foster togetherness in moral leadership; (10) involving family and community members as partners; and (11) evaluating the character of the school both towards school staff as character educators and students in manifesting good character (Lickona, 1991).

Moral conditioning as the initial stage of implementing character education in a micro context, needs to be continued to the stage of moral training. However, moral conditioning in character education is not perfect, when class-based character education designs are still dominated by conventional learning. That is, no matter how good moral conditioning is designed in order to implement character education based on moral intelligence, it will not be effective if teaching and learning activities in the teacher's classroom still display the following characteristics: teacher centered, expository dominance, textual orientation, low-level cognitive orientation and transfer of knowledge. Moral training design in developing moral intelligence demands a shift from 
Development of Citizenship Learning Based on Moral Intelligence as...

conventional learning to innovative learning. Why is that? Because character education with conventional learning patterns will only teach moral education only as textual and does not prepare students to respond to contradictory lives (Zubaedi, 2011).

For this reason, it is time for schools and colleges as one of the carriers of character education to creatively improve and develop innovative learning. The shift of conventional learning towards innovative learning patterns is a requirement in character education to be able to develop moral intelligence effectively. The shift in question can be displayed as in the following table:

Table 1. Learning Shift

\begin{tabular}{ll}
\hline Conventional Learning & Innovative Learning \\
\hline Teacher Centered Approach & Student Centered Approach \\
\hline Expository Domination & Multi models and methods \\
\hline Minim media & Multimedia \\
\hline Textbook Center & Multi of Learning source \\
\hline Verbalistic Learning & Contextual Learning \\
\hline Evaluate low-level cognitive & Evaluation: Cognitive, Affective and \\
dominance (C1, C2) & Psychomotor \\
\hline
\end{tabular}

Teacher position as transfer of knowledge

Teacher Position as director of learning

Source: Setiawan (2019)

The Department of Pancasila and Civic Education of Social Science Education in Universitas Negeri Medan has started creative efforts in developing innovative learning by developing moral intelligence-based civic learning, which is designed to produce teaching and learning activities that are more effective and meaningful in cultivating the character values of students. Innovative citizenship learning is a conducive condition for training morals to develop students' moral intelligence. Moral training is an important part of the strategy for developing moral intelligence. Through moral training, citizenship learning is not limited to moral knowledge but continues at the stage of moral feeling and moral action which synergistically contribute to the development of students' moral intelligence. The application of moral training in innovative learning in civics learning is expected to: (1) develop comprehensive moral intelligence; (2) providing a varied learning experience with a pleasant learning atmosphere; (3) students are more critical and creative; (4)) increases emotional maturity; and (5) willing to participate in the 
change process. Moral training becomes more important, when it is related to the goals of moral education to be achieved.

With regard to the relationship between innovative learning and character education, it is appropriate for a professional educator to be able to design a character lesson plan / RPS (Setiawan, et al., 2018) as a moral training scenario in developing the moral intelligence of students. In compiling character RPS, lecturers as compilers of learning scenarios, need to identify which main character values will be conditioned and trained to students. However, the purpose of this research is that the researcher has determined the main character values that have been determined by the State University of Medan, namely the six pillars of character (citizenship, justice, responsibility, honor, care, and trustworthiness) in realizing the character building university. The six pillars of character, and a description of the values of the main characters (indicators) that the researcher tries to develop are presented in the following table:

Table. Main Character Values

\begin{tabular}{|c|c|c|c|}
\hline No & $\begin{array}{c}\text { Main } \\
\text { Character }\end{array}$ & & Indicator \\
\hline \multirow[t]{6}{*}{1} & Citizenship & 1 & Implementing rights and obligations as citizens \\
\hline & & 2 & Obeying the laws and regulations \\
\hline & & 3 & Respect the government \\
\hline & & 4 & $\begin{array}{l}\text { Associating without distinguishing ethnicity, religion, race, } \\
\text { and class }\end{array}$ \\
\hline & & 5 & Willing to cooperate \\
\hline & & 6 & Be democratic \\
\hline \multirow[t]{6}{*}{2} & Fright & 1 & Implement the principle of equal standing before the law \\
\hline & & 2 & Stand up for others who are treated unfairly \\
\hline & & 3 & Do not want more / have something that is not right \\
\hline & & 4 & Not discriminatory \\
\hline & & 5 & Appreciate the work \\
\hline & & 6 & make a fair decision \\
\hline \multirow[t]{6}{*}{3} & Responsible & 1 & $\begin{array}{l}\text { Completing responsible for each job assigned to } \\
\text { completion. }\end{array}$ \\
\hline & & 2 & Does not find fault with others. \\
\hline & & 3 & Daring to take risks for the actions that are carried out. \\
\hline & & 4 & Do your best \\
\hline & & 5 & Set a good example \\
\hline & & 6 & $\begin{array}{l}\text { Carrying out every decision that has been taken } \\
\text { appropriately and responsibly. }\end{array}$ \\
\hline 4 & Respectful & 1 & Treat others with respect \\
\hline
\end{tabular}




\begin{tabular}{|c|c|c|c|}
\hline \multirow[t]{6}{*}{ No } & $\begin{array}{c}\text { Main } \\
\text { Character }\end{array}$ & \multicolumn{2}{|r|}{ Indicator } \\
\hline & & 2 & Maintain order together \\
\hline & & 3 & Tolerance \\
\hline & & 4 & Applying ethics and courtesy \\
\hline & & 5 & Able to keep state secrets \\
\hline & & 6 & $\begin{array}{l}\text { Wanting live anywhere in the territory of the Republic of } \\
\text { Indonesia. }\end{array}$ \\
\hline \multirow[t]{6}{*}{5} & Caring & 1 & Sympathy \\
\hline & & 2 & Empathic \\
\hline & & 3 & Helpful attitude \\
\hline & & 4 & Active participation \\
\hline & & 5 & Wanting forgive \\
\hline & & 6 & Wanting to fight for the public interest \\
\hline \multirow[t]{6}{*}{6} & Trustworthy & 1 & Honest \\
\hline & & 2 & Do not take what is not right \\
\hline & & 3 & Reliable \\
\hline & & 4 & Confidence \\
\hline & & 5 & Have a loyal attitude \\
\hline & & 6 & Building good reputation \\
\hline
\end{tabular}

Source: Research 2020

The main character values in the table above are valuable values that need to be developed through the value learning process (Halstead \& Taylor, 2000) and are packaged through the application of moral-based learning to cultivate character values towards students. In this study, the development of moral intelligence-based civics learning will be complemented by a value-clarifying technique known as the Values Clarification Technique (VCT). Hall explained that VCT as values clarification that mean a methodology or process which help a person to discover values through important choices he has made and is continually, in fact, acting upon in and through his life (Hall, 1973).

Through VCT, students are trained to determine life values that are appropriate to their life goals and internalize them into their personal as a guide in reasoning, behaving and behaving morally. Moral training with VCT is considered appropriate in applying value learning, and can be modified creatively by educators in developing students' moral intelligence. 


\section{B. Method}

This study applies the development research model of Borg \& Gall. R\&D development model. In its implementation, this R\&D research follows the procedures developed by (Sugiyono, 2017). The research subjects include: (1) lecturer who teaches Civics Education (Civics) as a core subject in the Department of PPKn, FIS Unimed; (2) students as a limited trial group; (3) 4 validation experts consisting of experts in the field of Citizenship Education material content.

With the research stages, namely preliminary; product design; product evaluation and product effectiveness test. Then to analyze the results of the assessment given by experts on the quality and feasibility of the product, the following Mean Score Percentage formula will be used:

Mean Score Percentage $=$ Total Score $/$ Maximum Score $\times 100 \%$

with criteria:

$$
\begin{aligned}
& 90 \% \leq \text { PRS } \leq 100=\text { Very Good } \\
& 80 \% \leq \text { PRS } \leq 90 \%=\text { Good } \\
& 70 \% \leq \text { PRS } \leq 80 \%=\text { Enough } \\
& 60 \% \leq \text { PRS } \leq 70 \%=\text { Less } \\
& 0 \% \leq \text { PRS } \leq 60 \%=\text { Very Less }
\end{aligned}
$$

\section{Finding and Discussion}

The research design of civic education textbook design based on moral intelligence as a systemic program for the culture of main character values through the following 4 stages, namely: (1) conducting preliminary research, (2) making textbook designs, (3) reviewing and testing textbooks in the framework of formative evaluation and product revision, and (4) product effectiveness testing.

The preliminary research stage is carried out by observing the teaching staff in the PPKn department and reviewing the sequence of character values that are implemented in each subject and there is no synergy between character values and Civics science, so there is a need for a textbook design that includes firm character values in any civics material content

The next stage is the product design is carried out by developing the formulation of learning outcomes or learning outcomes of introductory civics science by integrating the existing concepts in the values of the main characters in the aspects of citizenship, justice, responsibility, and respect. respectful), caring, can be trusted (trustworthy) 
Development of Citizenship Learning Based on Moral Intelligence as...

which has been designed integrated with moral intelligence as a systemic program for the culture of the main character values

This stage is the final step in this research, namely the product evaluation stage which consists of evaluations from validators, namely media and learning material experts, and small group students. To see the overall evaluation results from both the expert team and users or small groups it can be seen that the results are presented in graphical form as follows;

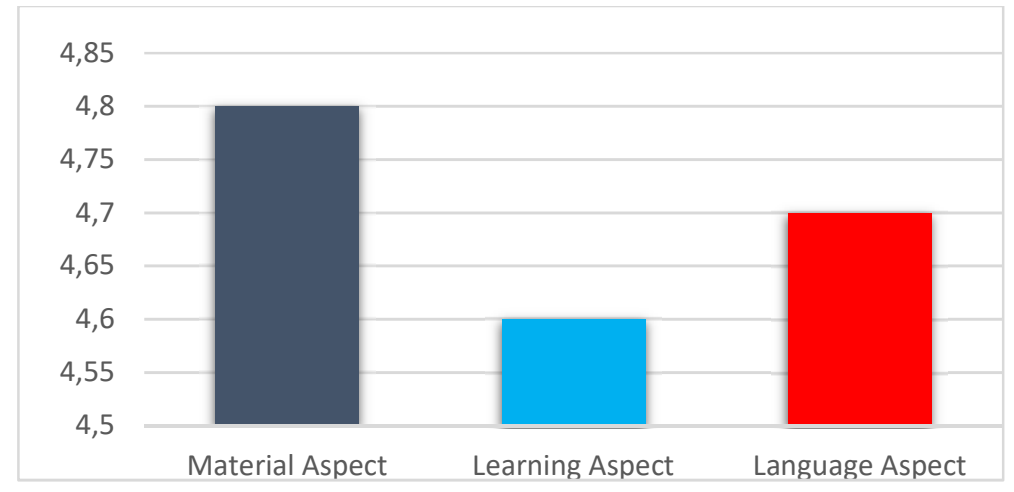

Source, October 2020

Picture. Results of Material and User Evaluations

Thus, from the picture, the evaluation of the content of citizenship education material based on moral intelligence as a systemic program for the culture of the main character values of students was carried out by a test of knowledge about moral intelligence content with the main character approach, namely citizenship, justice, and responsibility. (Responsible), respect (respectful), care (caring), can be trusted (trustworthy) has been tested for its validity and has an effect on increasing student interest in learning and increasing the value of these main characters. The book is very appropriate to be used as a handbook or mandatory that is updated and innovative and is able to instill the main character of students who have been eroded in this era and develop a spirit of awareness based on moral intelligence in the end being able to implement a sense of citizenship, justice, and responsibility Responsible, Respectful, Caring, Trustworthy.

Contribution to the development of learning books with content of moral intelligence with the main character traits, namely citizenship, fairness, responsibility, respect, caring, trustworthiness can be seen from the attitude that is progressive or has a significant increase in student understanding. The following is the attitude scale test table based on the picture as follows; 


\section{Contribution of Main Characters}

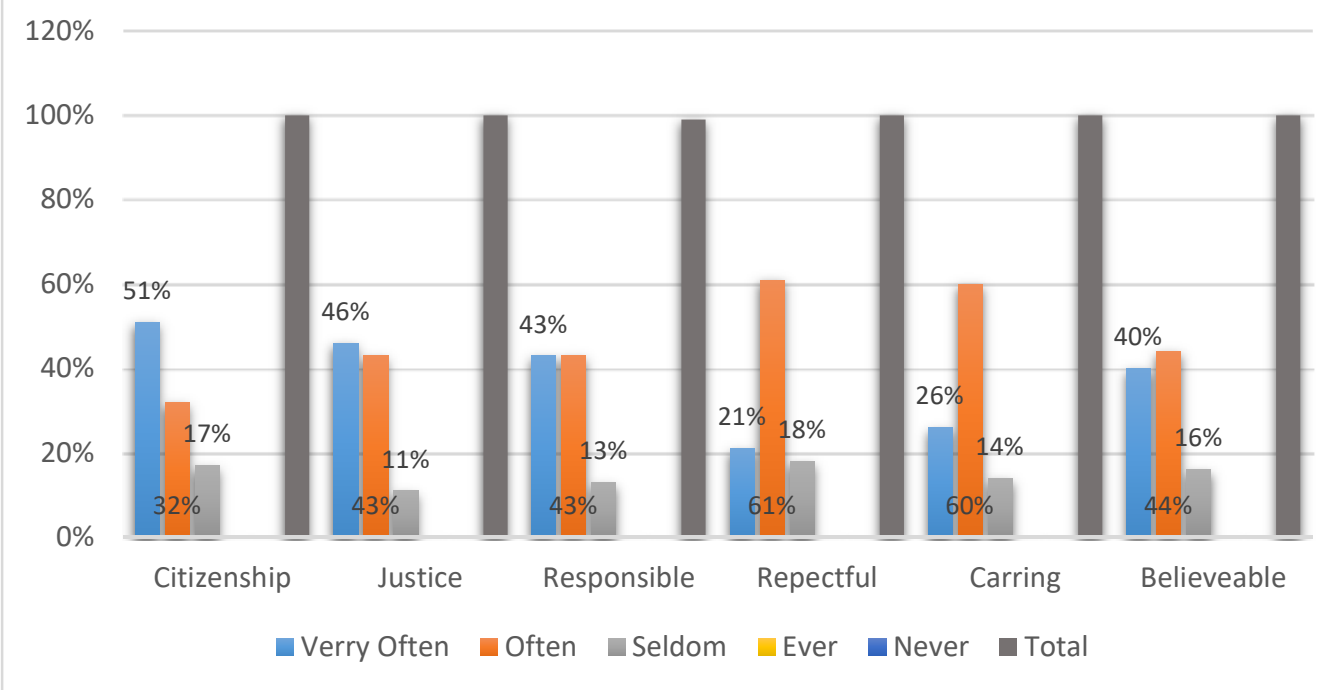

Source, October 2020

Image of Attitude scale Test Results

The description in the figure shows that the contribution of the development of textbooks produced as a product in this study contributes to the attitudes of the main characters by $85 \%$. The highest contribution was in the national character of $51 \%$; followed by a fairness character of $46 \%$; then the character of responsibility was $43 \%$; and trustworthiness of $40 \%$; then the caring character was $26 \%$, and the lowest was the honorary character by $21 \%$.

The content of Civics material based on moral intelligence developed by the researcher obtained an average score of 4.3, namely 4 for the text component, 4.5 for the content component, 4 for the supporting literature component, 4.5 for the user component. The total average score for all components reaches 4.3 or is in the "Good" category. Thus, animated videos are still worth testing without having to revise them. If the assessment criteria are in percentage, the value achieved gets $85 \%$ or the conclusion is valid.

This evaluation was carried out by testing 5 students out of 30 first semester students of the Civics Education Department, Faculty of Social Sciences, Medan State University. The average score for the media aspect from the results of the assessment of five students reached 4.68 in the "Very Good" category, the average score for the material aspect was 4.7 with the "Very Good" category and the average score for the 
Development of Citizenship Learning Based on Moral Intelligence as...

learning aspect was 4, 6 with the "Very Good" category, and the language aspect gets an average score of 4.7 with the "Very Good" category.

The average score for the three aspects assessed in this first trial reached 4.68 in the "Very Good" category. Based on these results the researchers found no fundamental deficiencies in the product that needed to be improved, both in terms of material, learning and language. Moral intelligence-based learning books as a systemic program for cultivating the values of the main character have been declared very good and if the percentage is $94.6 \%$.

The results of the evaluation of the use of this book are that the average student answers very well. Thus, learning books based on moral intelligence as a systemic program for cultivating the values of the main characters are very worthy to be used as a guide for students, especially those in the Pancasila and Civic education majors.

This finding is also supported some previous researches such as Hassan Zohoor (2003) state from the result of his researchi is Pancasila and civic education is essential subject to guide the students be human that has good thought and beheviour. Learning method used theory, rule, and supervising method. Supervising method in teaching moral is more effectivnes than educating with theory and rule method. According to Falaq (2020) that citizenship education has the challenge of presenting critical, constructive and innovative thinking knowledge and skills by not leaving emotional, social and spiritual intelligence firmly entrenched as mandated in the Pancasila and the 1945 constitution. Julkifli, Marsuki, and Endang (2020) in their research concluded that Learning strategies Pancasila and citizenship education that contains the development of students' character every step of the preliminary, core and closing activities carried out through habituation, communication, and exemplary activities. Then the religious character, nationalist, independent, mutual cooperation and integrity can be done well in every process of teaching and learning activities. From the above findings can conclude that to build the good character to the students need the citizenship learning or with applying a subject that develop the civilization learning based on moral intelligent to interpret good values in the modern social life now.

\section{Conclusions}

In this study, it can be concluded that the products produced in this study, namely civics textbooks (moral and character perspectives) were declared valid by the validators and deemed suitable for use as textbooks in the Civics Science course. The results of this 
study also show that the application of textbooks can increase the values of the main characters, namely; citizenship, justice, responsibility, honor, care and trustworthiness. The most significant increase is contributing to knowledge understanding and changes in attitudes to the value of citizenship characters. Meanwhile, the level of understanding and contribution of attitudes that tend to be less than optimal is the value of the character of honor. This is because they have not cultivated their attitude to treat others with respect, maintain mutual order, are tolerant, apply ethics and politeness, can keep State secrets, want to live anywhere in the territory of the unitary Republic of Indonesia.

It is hoped that the textbooks produced in this research can be used as a joint reference in developing moral intelligence-based character education in Pancasila and Civic Department, and also used as a source of reference in character education for Pancasila and Civic Departments throughout Indonesia which are members of Pancasila Education Professional Association and Indonesian Citizenship (AP3KnI). This is based on findings that show; (1) textbooks produced in this study can assist lecturers in implementing moral intelligence-based civics learning; (2) can improve the moral competence of students as students with character; (3) cultivate the values of the main characters, namely: citizenship, fairness, respect, responsibility, caring, and trustworthy in Pancasila and Civic Department of Social Science Faculty in Universitas Negeri Medan, as well as in realizing the character building university at Universitas Negeri Medan.

\section{Bibliography}

Adisusilo, J., 2012. Pembelajaran Nilai Karakter. Jakarta: PT. Raja Grafindo Persada.

Borba, M., 2008. Building Moral Intelligence, The Seven Essential Virtues that Teach Kids to do The Right Think. Jakarta: Gramedia Pustaka Utama.

Goleman, D., 2007. Emotional Intelligence. 7nd ed. Jakarta: Gramedia Pustaka Utama.

Hajar, I., 2011. Strategi Pembentukan Karakter Mahasiswa Melalui Pendidikan Karakter. Medan: Universitas Negeri Medan.

Hall, B., 1973. Value Clarification as Learning Process. New York: Paulist Press.

Halstead, J. M. \& Taylor, M. J., 2000. Learning and Teaching about Values: A Review of Recent Research. Cambridge Journal of Education, 30(2), pp. 169-201.

Kirschenbaum, H., 2000. From Values Clarification to Character Education: A Personal Journey. The Journal of Humanistic Counseling, Education and Development, 39(1), pp. 4-20. 
Development of Citizenship Learning Based on Moral Intelligence as...

Lickona, T., 1991. Educating for Character: How Our Schools Can Teach Respect and Responsibility. New York: Bantan Books.

Sanusi, H., 1993. Quo Vadis Pendidikan IPS?. Jurnal Pendidikan IImu Sosial, 1(2), p. 9.

Setiawan, D. \& Sitompul, H., 2017. The Real Development of Authentic Assessment Based on Characters of Primary Students. Medwell Journal, 12(6), pp. 40-51.

Setiawan, D., Sitorus, J. \& Natsir, M., 2018. Inhibiting Factor of Primary School Teacher Competence in Indonesia: Pedagogic and Professionalism. Asian Social Science Journal, 14(6), pp. 30-42.

Siburian, P., 2011. Penanaman dan Implementasi Nilai Karakter Tanggung-Jawab. Medan: Universitas Negeri Medan.

Sinaga, B., 2011. Penanaman Nilai Karakter Berbangsa. Medan: Universitas Negeri Medan.

Soedarsono, S., 2009. Karakter Mengantar Bangsa, dari Gelap Menuju Terang. Jakarta: Elex Media Komputindo, Kompas Gramedia.

Sugiyono, 2017. Metode Penelitian Kuantitatif, Kualitatif, dan R \& D. Bandung: Alfabeta.

Suyatno, 2009. Urgensi Pendidikan Karakter. Jakarta: Depdiknas.

Winarni, S., 2013. Integrasi Pendidikan Karakter Dalam Perkuliahan. Pendidikan Karakter, 4(1), pp. 95-107.

Zubaedi, 2011. Desain Pendidikan Karakter Konsepsi dan Aplikasinya dalam Lembaga Pendidikan. Jakarta: Kencana. 